\title{
Plasma concentrations of lignocaine during fibreoptic bronchoscopy
}

\author{
J EFTHIMIOU, T HIGENBOTTAM, D HOLT, GM COCHRANE \\ From the Department of Thoracic Medicine and National Poisons Unit, New Cross Hospital, Guy's \\ Health District, London
}

ABSTRACT Peak plasma concentrations of lignocaine were recorded in 41 patients receiving topically applied lignocaine for fibreoptic bronchoscopy. Adequate anaesthesia was achieved in all patients with an average dose per unit weight of $9.3 \pm 0.5 \mathrm{mg} / \mathrm{kg}(\mathrm{SEM})$ giving a mean peak plasma concentration of $2.9 \pm 0.5 \mathrm{mg} / 1^{-1}(\mathrm{SEM})( \pm$ SE 0.5$)$. The plasma concentration exceeded toxic levels of $5.0 \mathrm{mg} / \mathrm{l}^{-1}$ in only two patients, and no complications were observed. Peak concentrations were influenced only by dose per unit weight administered and not by factors considered likely to influence mucosal absorption from the bronchial tree, such as sputum production, airflow obstruction, or cigarette smoking. A major proportion of the total dose of lignocaine was required to anaesthetise the nose, pharynx, and larynx, only a small proportion being needed for the bronchial tree. Lignocaine gel $(2 \% \mathrm{w} / \mathrm{v})$ was preferred by patients, and in a study of 10 volunteers, produced lower plasma concentrations when used as a topical anaesthetic than did lignocaine aerosol $(10 \% \mathrm{w} / \mathrm{v})$ or lignocaine solution $(4 \% \mathrm{w} / \mathrm{v})$.

Fibreoptic bronchoscopy is safe and simple, but topical anaesthesia of the upper respiratory tract is necessary for adequate examination. Lignocaine is commonly used but is well absorbed from mucosal surfaces, producing significant plasma concentrations $^{1}$ and may therefore not be ideal. ${ }^{2}$ Lignocaine toxicity is related to plasma concentrations ${ }^{3}$ and levels in excess of $5 \mathrm{mg} / \mathrm{l}^{-1}$ may result in convulsions ${ }^{4}$ or heart block. ${ }^{5} 6$

Little is known of the comparative mucosal absorption of the common preparations of lignocaine: $2 \% \mathrm{w} / \mathrm{v}$ gel $; 4 \% \mathrm{w} / \mathrm{v}$ solution (also $1 \% \mathrm{w} / \mathrm{v}$ ), and $10 \% \mathrm{w} / \mathrm{v}$ aerosol. Lignocaine solution when applied to the respiratory tract is absorbed from mucosa of the tracheobronchial tree or even alveoli.? However, there is little information on the effects of lung disease or smoking on lignocaine absorption from the airways.

We have studied 41 patients undergoing fibreoptic bronchoscopy, to determine the safe limits for topical administration of lignocaine, and to determine whether higher total doses were needed in

Address for reprint requests: Tim Higenbottam, Respiratory Physiology Department, Papworth and Addenbrooke's Hospitals, Cambridge CB3 8RE. patients with lung disease. Separately, absorption through buccal and nasal mucosa has been studied in volunteers.

\section{Methods}

\section{PATIENTS STUDY}

Forty-one patients undergoing fibreoptic bronchoscopy were studied, each having given informed consent. On the morning of study each patient was asked to produce as much sputum as possible and sputum volume was measured. Spirometry was performed and a modified MRC questionnaire on respiratory symptoms and smoking habit was completed by each patient. No patient had clinical evidence of liver disease; haematological and biochemical investigations were normal in all.

Premedication with intramuscular omnopon $(0.17 \mathrm{mg} / \mathrm{kg})$ and atropine $(0.005 \mathrm{mg} / \mathrm{kg})$ was administered one hour before study, patients having fasted for five hours. Endoscopy was performed via the transnasal route. In 32 patients sufficient sprays (10 $\mathrm{mg}$ per actuation) of a lignocaine aerosal $(10 \% \mathrm{w} / \mathrm{v})$ were applied to the anterior nares and oropharynx, five minutes before passing the bronchoscope. In nine patients, lignocaine gel $(2 \% \mathrm{w} / \mathrm{v})$ was applied to the anterior nares from a $10 \mathrm{ml}$ syringe 
filled with gel.

The amount of $4 \% \mathrm{w} / \mathrm{v}$ lignocaine solution (and $1 \% \mathrm{w} / \mathrm{v}$ solution) injected through the bronchoscope to each area of the airway was recorded.

Total lignocaine dose, percentage of aerosol and percentage of solution applied above and below the vocal cords were calculated for each patient and total dose per unit body weight derived. Venous blood samples were taken before, during, and 180 minutes after bronchoscopy at intervals of 10 minutes initially, then at 20 minute intervals over the last 60 minutes. Plasma lignocaine concentrations were measured by a gas liquid chromatographic technique. ${ }^{9}$ The highest plasma concentration, and time to this peak, were determined. The influence of dose per unit weight, smoking habit, sputum volume, and degree of airflow obstruction (percentage of predicted value for FEV $^{1}$ ) on peak plasma lignocaine concentrations was assessed using a stepwise multiple regression analysis. ${ }^{10}$

\section{VOLUNTEER STUDY}

A further group of 10 volunteers, who had given informed consent, were studied. Five on separate days in random order, ejther gargled and drank lignocaine solution $(4 \% \mathrm{w} / \mathrm{v})$, or had lignocaine aerosol $(10 \% \mathrm{w} / \mathrm{v})$, applied to their oropharynx. Excess amounts were swallowed as is the usual case during endoscopy. A similar dose per unit body weight was used with each preparation $(6.8 \mathrm{mg} / \mathrm{kg})$. Venous blood was again taken at 10 minute intervals initially for the first hour, then at 20 minute intervals for the second hour to determine plasma lignocaine concentrations. Because of the unpleasant nature of the aerosol, a lower dose per unit body weight $(2 \cdot 2 \mathrm{mg} / \mathrm{kg})$ was applied to the anterior nares in five volunteers and was contrasted with effect of the same dose per unit body weight of lignocaine gel $(2 \% \mathrm{w} / \mathrm{v})$. On separate days, the two lignocaine preparations were studied in random order and peak plasma lignocaine concentrations and time to peak were determined. Comparisons of the two preparations were made using paired $t$ tests. ${ }^{11}$

\section{Results}

\section{PATIENT STUDY}

The results are recorded in the figure. A mean total dose of $623 \pm 41 \cdot 1 \mathrm{mg}$ (SEM) lignocaine was administered to our 41 patients. The average dose per unit body weight was $9.3 \pm 0.5 \mathrm{mg} / \mathrm{kg}$ (SEM) which gave an average peak plasma concentration of $2.9 \pm 0.5 \mathrm{mg} / \mathrm{l}^{-1}$ (SEM). Although two patients had peak concentrations in excess of a recognised

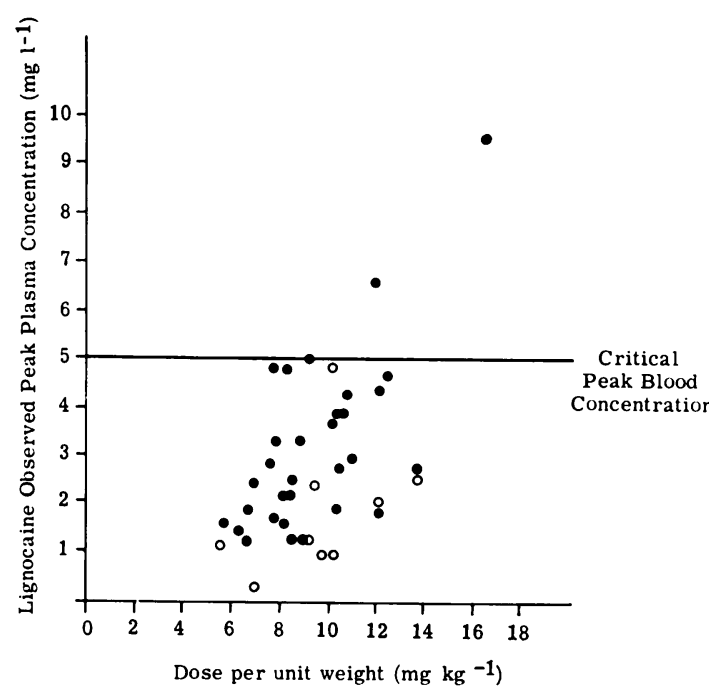

Figure The peak plasma concentration of each of the 41 patients plotted against the dose per unit weight of lignocaine received during fibreoptic bronchoscopy. The closed circles represent patients who received $10 \%$ aerosol then lignocaine solution and the open circles those who received $2 \%$ gel then lignocaine solution. $A$ recognised critical toxic concentration of lignocaine in plasma is shown.

critical level for toxicity 45615 taken to be $5 \mathrm{mg} / \mathrm{l}^{-1}$, none revealed clinical evidence of toxicity during or after the procedure.

Peak plasma concentrations only correlated significantly with dose per unit body weight $(\mathrm{r}=$ $0.59 ; \mathrm{p}<0.05), 42 \%$ of the variation in peak plasma concentration being attributable to dose per unit body weight. Less than $5 \%$ of the remaining variation was attributable to sputum volume, cigarette consumption or percent predicted $\mathrm{FEV}_{1}$, none having any significant influence on peak plasma concentrations. Similarly, none of these variables significantly affected the total dose or dose per unit body weight of lignocaine administered during the endoscopy.

A comparison of the peak plasma concentrations observed in patients receiving aerosol/solution was made with patients receiving gel/solution regimens. Use was made of analysis of covariance to correct for differences in dose per unit body weight. ${ }^{11}$ There was no significant difference between the two regimens in the peak plasma concentrations of lignocaine $(p>0.05)$ (see figure). The average time to peak concentrations was 42.6 minutes ( \pm SE 3.02) in aerosol patients and 48.4 minutes ( \pm SE 6.83) in patients receiving lignocaine gel. 
Considering the relative amounts of lignocaine administered to different sites in the airways, on average only $22 \pm 1 \cdot 2 \%$ (SE) was applied as aerosol to the nose and pharynx. Over $50 \%$ of the total dose was administered as $4 \% \mathrm{w} / \mathrm{v}$ lignocaine solution to the pharynx and larynx with a remaining $23 \cdot 5 \pm$ $2.1 \%(\mathrm{SE})$ as $1 \% \mathrm{w} / \mathrm{v}$ lignocaine solution to the bronchial tree. In nine patients receiving gel, an average $25 \pm 4.5 \%$ (SE) was administered to the nose as gel and they received a greater proportion of the total dose as $1 \% \mathrm{w} / \mathrm{v}$ lignocaine down the bronchoscope to the bronchial tree, $38.4 \%$ ( \pm SE $4.2 \%$ ). Patients receiving both regimens had similar dose ranges of lignocaine (see figure).

\section{VOLUNTEER STUDY}

The results are recorded in the table. A comparison of absorption from the oropharynx of lignocaine aerosol and solution showed that the $4 \% \mathrm{w} / \mathrm{v}$ solution gave significantly higher peak plasma concentrations than the aerosol, $2.4 \mathrm{mg} / \mathrm{l}$ compared with $1.9 \mathrm{mg} / \mathrm{l}(\mathrm{p}<0.05)$. This average concentration was achieved more quickly in solution ( 24 minutes) than for aerosol $(50$ minutes) $(\mathrm{p}<0.05)$.

When one-third of this dose was applied to the nose, lignocaine aerosol was absorbed better than gel, giving peak plasma concentrations of $0.8 \mathrm{mg} / 1$ compared with $0.52 \mathrm{mg} / \mathrm{l}$ for gel $(\mathrm{p}<0.05)$. Time to peak for aerosol was 46 minutes compared with only 34 minutes for the gel $(p<0.05)$.

\section{Discussion}

Adequate anaesthesia was achieved in all 41 patients enabling full bronchoscopic examination. The low risk associated with topical lignocaine anaesthesia to the upper airways was confirmed ${ }^{12}$. In 32 patients this was provided on average by 14 sprays of $10 \%$ $\mathrm{w} / \mathrm{v}$ lignocaine aerosol to the nose and throat, $8 \mathrm{ml}$ of $4 \% \mathrm{w} / \mathrm{v}$ lignocaine solution to the pharyn and vocal cords, and $14 \mathrm{ml}$ of $1 \% \mathrm{w} / \mathrm{v}$ solution for the bronchial tree. Even with our wide range in total dosage, larger than reported in earlier studies, ${ }^{8}$ most patients had peak plasma concentrations of lignocaine well below a toxic level. Use of an alternative regimen, in which lignocaine gel was applied to the nose (an average of $8 \mathrm{ml}, 4 \mathrm{ml}$ to each nostril), followed by lignocaine solution $4 \% \mathrm{w} / \mathrm{v}$ above the vocal cords and $1 \% \mathrm{w} / \mathrm{v}$ below the cords, proved to be more acceptable to patients. It gave slightly (but not significantly) lower peak plasma concentrations but was not considered less anaesthetically powerful and caused less epiphora than lignocaine aerosol.

Only two patients had peak plasma concentrations in excess of $5 \mathrm{mg} / \mathrm{l}$. One with a high concentration $(9.6 \mathrm{mg} / \mathrm{l})$ (although revealing no clinical evidence of renal or hepatic dysfunction at the time of bronchoscopy) was found on postmortem examination four weeks later to have extensive liver metastases from his bronchial carcinoma. It is possible that the high peak concentration represented occult metabolic hepatic dysfunction. Renal and hepatic function are important in the clearance of lignocaine, and previous reports of high peak plasma concentrations after topical lignocaine have been confined to patients with dysfunction. ${ }^{13}$

In this study we did not show airflow obstruction, sputum production, or cigarette smoking habit to have any influence on peak plasma lignocaine concentrations. This contrasts with previous observations where tracheobronchial absorption of

Table Results of administrationof lignocaine to volunteers by oropharyngeal and nasal routes

\begin{tabular}{|c|c|c|c|c|c|}
\hline $\begin{array}{l}\text { Volunteer (or } \\
\text { Subject }\end{array}$ & $\begin{array}{l}\text { al study) } \\
\text { Dose of lignocaine } \\
(\mathrm{mg} / \mathrm{kg})\end{array}$ & $\begin{array}{l}4 \%(w / v) \text { solution of lignocaine } \\
\text { Peak plasma concentrations } \\
(\mathrm{mg} / \mathrm{l})\end{array}$ & $\begin{array}{l}\text { Time to peak } \\
(\min )\end{array}$ & $\begin{array}{l}10 \%(w / v) \text { aerosol of lignocaine } \\
\text { Peak plasma concentrations } \\
(\mathrm{mg} / \mathrm{l})\end{array}$ & $\begin{array}{l}\text { Time to peak } \\
(\min )\end{array}$ \\
\hline $\begin{array}{l}1 \\
2 \\
3 \\
4 \\
5\end{array}$ & $\begin{array}{l}6 \cdot 2 \\
6 \cdot 8 \\
7 \cdot 0 \\
6 \cdot 0 \\
8 \cdot 0\end{array}$ & $\begin{array}{l}2.2 \\
3.4 \\
1.9 \\
1.9 \\
2.8\end{array}$ & $\begin{array}{l}20 \\
20 \\
30 \\
20 \\
30\end{array}$ & $\begin{array}{l}1.9 \\
1.8 \\
1.8 \\
1.7 \\
2.5\end{array}$ & $\begin{array}{l}30 \\
60 \\
60 \\
60 \\
40\end{array}$ \\
\hline Mean value & $6 \cdot 8$ & $2 \cdot 4$ & 24 & $1 \cdot 9$ & 50 \\
\hline $\begin{array}{l}\text { Volunteer (na } \\
\text { Subject }\end{array}$ & $\begin{array}{l}\text { sal study) } \\
\text { Dose of lignocaine } \\
(\mathrm{mg} / \mathrm{kg})\end{array}$ & $\begin{array}{l}10 \%(w / v) \text { aerosol of lignocaine } \\
\text { Peak plasma concentrations } \\
(\mathrm{mg} / \mathrm{l})\end{array}$ & $\begin{array}{l}\text { Time to peak } \\
(\mathrm{min})\end{array}$ & $\begin{array}{l}2 \%(w / v) \text { gel of lignocaine } \\
\text { Peak plasma concentrations } \\
(m g / l)\end{array}$ & $\begin{array}{l}\text { Time to peak } \\
(\min )\end{array}$ \\
\hline $\begin{array}{r}6 \\
7 \\
8 \\
9 \\
10\end{array}$ & $\begin{array}{l}2 \cdot 3 \\
1 \cdot 98 \\
2 \cdot 0 \\
2 \cdot 8 \\
2 \cdot 1\end{array}$ & $\begin{array}{l}0.7 \\
1.0 \\
0.6 \\
0.5 \\
1.2\end{array}$ & $\begin{array}{l}45 \\
35 \\
60 \\
50 \\
40\end{array}$ & $\begin{array}{l}0.4 \\
0.7 \\
0.4 \\
0.3 \\
0.8\end{array}$ & $\begin{array}{l}30 \\
30 \\
28 \\
50 \\
30\end{array}$ \\
\hline Mean value & $2 \cdot 2$ & 0.8 & 46 & 0.5 & 34 \\
\hline
\end{tabular}


lignocaine was influenced by the presence of mucous or epithelial changes. ${ }^{7}$ Cigarette smoking could, for example, increase absorption of lignocaine through promotion of changes in bronchial epithelium, ${ }^{14}$ or alternatively could increase clearance by enzyme induction. ${ }^{15}$ Mucosal absorption is therefore either unaffected by airway disease, which seems unlikely, or only a small fraction of the total dose of lignocaine is actually absorbed from the tracheobronchial airways. The latter appears more likely as only $20-40 \%$ of the total lignocaine dose was applied to the bronchial tree, most of this being coughed up and swallowed. The delay of $\mathbf{4 0}$ minutes or more between first administration of lignocaine to peak plasma concentration, would also be consistent with largely gastrointestinal absorption. ${ }^{2}$

Patients with chronic obstructive bronchitis who may have heightened bronchial reactivity ${ }^{16}$ did not require more lignocaine to achieve anaesthesia. Apart from the need to suppress pain associated with transnasal passage of the fibreoptic bronchoscope, the function of topical anaesthesia is to suppress coughing. Most sensory receptors responsible for coughing are concentrated around the pharynx and in the larynx above and just below the vocal cords. ${ }^{17}$ This was the area to which the greater proportion of the lignocaine was applied. Local mucosal absorption, to any extent, is unlikely from such a site, as excess fluid in the pharynx is swallowed.

Peak plasma concentrations of lignocaine are functions of rate of mucosal absorption, distribution in tissues, and rate of elimination of the drug from the body. The differences in peak plasma concentrations in studies of volunteers are likely to reflect variations in rate of mucosal absorption. ${ }^{3}$ Absorption was more rapid and complete with the $4 \% \mathrm{w} / \mathrm{v}$ solution of lignocaine than from the other two preparations. Lignocaine was least well absorbed in gel form. When deciding on the most suitable topical anaesthesia, consideration should be given to absorption, as an ideal topical agent should achieve local anaesthesia with little absorption, producing low plasma concentrations. On these grounds the gel preparation of $2 \%(w / v)$ lignocaine would appear most suitable. It provides adequate topical anaesthesia particularly for nasal passages, causing little pain and epiphora, as well as acting as a lubricant. As excess gel is swallowed, none is likely to enter the trachea, unlike the aerosol.

In conclusion, topical anaesthesia with lignocaine during fibreoptic bronchoscopy has again proved safe. Only two out of 41 patients developed peak plasma concentrations associated with toxicity, and all patients remained free of toxic symptoms. Most of the topical anaesthetic was required for the nose, pharynx, and larynx. Application of lignocaine gel $2 \% \mathrm{w} / \mathrm{v}$ to the nose followed by solution to the larynx appeared a more satisfactory regimen than applying lignocaine aerosol $10 \% \mathrm{w} / \mathrm{v}$ to the nose.

\section{References}

${ }^{1}$ Le lorier J, Larochelle P, Bolduc P et al. Lidocaine blood concentrations during and after endoscopic precedures. Int J Clin Pharm Biopharm 1979;17:53-5.

${ }^{2}$ Credle WF, Smiddy JF, Elliott CR. Complications of fibreoptic bronchoscopy. Am Rev Respir Dis 1974;109: 67-72.

${ }^{3}$ Melmon KL, Rowland M, Sheiner L, Trager W. In: DS Davies, BNC Prichard, eds. Drugs in relation to their plasma concentrations. New York: Macmillan. 1973: 107-8.

${ }^{4}$ Foldes FF, Molloy R, McNall PG, Koukal LR. Comparison of toxicity of intravenously given local anaesthetic agents in man. JAMA 1960;172:1493-5.

${ }^{5}$ Cacace L. Sinus standstill from Lidocaine. JAMA 1973; 224:1428-9.

- Gupta PK, Lichstein E, Chadda KD. Lidocaine induced heart block in patients with bundle branch block. Am J Cardiol 1974;33:487-90.

7 Pelton DA, Daly M, Cooper PD, Conn AW. Plasma lidocaine concentrations following topical aerosol application to the trachea and bronchi. Canad Anaesth Soc $J$ 1970;17:250-5.

${ }^{8}$ Patterson JR, Blaschke TF, Hunt Jr KK, Meffin PJ. Lidocaine blood concentrations during fiberoptic bronchoscopy. Am Rev Respia Dis 1975;112:53-7.

9 Holt DW, Flanagan RJ, Hayler AM, Loizou M. Simple gas-liquid chromatographic method for the measurement of mexiletine and lignocaine in blood-plasma or serum. J Chromatog 1979;169:295-301.

${ }^{10}$ Draper NR, Smith H. Applied regression analysis. New York: John Wiley, 1966:171.

11 Armitage P. Statistical methods in medical research. Second edition. Oxford: Blackwell Scientific Publications, $1975 ; 115 ; 288$.

12 Curran J, Hamilton C, Taylor T. Topical analgesia before tracheal intubation. Anaesthesia 1975;30:765-8.

13 Thomson PD, Melmon KL, Richardson JH et al. Lidocaine pharmokinetics in advanced heart failure. Liver disease and renal failure in humans. Ann Intern Med 1973;78:499-506.

${ }^{14}$ Simani AS, Inoue S, Hogg JC. Penetration of the respiratory epithelium of Guinea pigs following exposure to cigarette smoke. Lab Invest 1974;31:75-81.

${ }^{15}$ Kozak PJ. Factors that influence theophylline metabolism. Western J Med 1979;131:319-20.

${ }^{16}$ Fletcher CM. Bronchial infection and reactivity in chronic bronchitis. J R Col Phys (Lond) 1968;2:183-9.

17 Boushey HA, Richardson PS, Widdicombe JG, Wise JM. The response of laryngeal afferent fibres to mechanical and chemical stimuli. J Physiol 1974;240:153-75. 